This work is licensed under Creative Commons Attribution 4.0 International (CC BY 4.0). [http://creativecommons.org/licenses/by/4.0/]

\title{
Moment ustania stosunku pracy przy skróconym okresie wypowiedzenia a wysokość odprawy z art. 8 ustawy z dnia 13 marca 2003 r. o szczególnych zasadach rozwiązywania z pracownikami stosunków pracy z przyczyn niedotyczących pracowników - luka extra legem
}

Joanna Radziszewska | Uniwersytet Gdański https://orcid.org/0000-0002-7687-7365

Słowa kluczowe: rozwiązanie stosunku pracy, skrócony okres wypowiedzenia, uprawnienia pracownicze, wysokość odprawy, zwolnienia grupowe

\section{Streszczenie}

Rozwiązanie umowy o pracę, zawartej na czas określony lub nieokreślony, w trybie ustawy z dnia 13 marca 2003 r. o szczególnych zasadach rozwiązywania z pracownikami stosunków pracy z przyczyn niedotyczących pracowników zwanej też "ustawą o zwolnieniach grupowych" - przy zastosowaniu skróconego okresu wypowiedzenia z art. 36 ustawy z dnia 26 czerwca 1974 r. Kodeks pracy, generuje wątpliwość dotyczącą momentu zakończenia tego stosunku prawnego. Ma ona bezpośredni wpływ na ustalenie wysokości odprawy, przysługującej pracownikowi na podstawie art. 8 pierwszej z wymienionych ustaw, w sytuacji gdy w czasie, o który został skrócony okres wypowiedzenia, upłynęły 2 lub 8 lat zakładowego stażu pracy.

W przepisach polskiego prawa brak regulacji, która rozstrzygałaby ten problem wprost, dlatego można postawić tezę, że mamy tu do czynienia z luką prawną extra legem. Przedmiotowe zagadnienie wielokrotnie było przedmiotem rozważań doktryny oraz Sądu Najwyższego. W latach 1990-1992 wydał on dwa orzeczenia, prezentujące przeciwstawne poglądy na tę kwestię. Taki stan rzeczy spowodował, że pojawiły się rozbieżności co do tego, które ze wskazanych rozwiązań jest z prawnego punktu widzenia prawidłowe. Przyczynił się też do utrwalenia wśród pracodawców i pracowników wątpliwości, jak interpretować przepisy, aby nie narazić się na spór sądowy. W związku z tym, że kwestia dotyczy tak ważnego tematu, jak uprawnienia pracownicze i świadczenia związane z zakończeniem stosunku pracy, ustawodawca powinien rozstrzygnąć ten problem poprzez wprowadzenie odpowiednich zapisów ustawowych, normujących wprost rozpatrywane zagadnienie. W ten sposób z polskiego systemu prawnego skutecznie zostałaby wyeliminowana kłopotliwa luka prawna. 
The moment of termination of employment relationship and the amount of severance pay of art. 8 Particular principles of dissolution of employment agreement due to reasons independent from employees act of 13 March 2003 - extra legem gap in the law (Summary)

Keywords: dissolution of an employment relationship, shortened period of notice, employee rights, sum of severance pay, collective redundancy

Termination of employment contract made, for a definite or indefinite amount of time, in compliance with regulations of the Particular principles of dissolution of employment agreement due to reasons independent from employees act of 13 March 2003 (also called "The Group Redundancy Act") and article $36^{1}$ of The Labour Code (consolidated text published in Journal of Laws 2018, item 917 as amended), raises doubts in regards to exact moment of termination of this relationship. It has direct impact on the determination of the exact amount of severance pay owed to the worker, in accordance with art. 8 of The Group Redundancy Act, in a situation wherein the period of notice has been shortened and the total employment time passes a 2 or 8 year point.

In no Polish statue are there regulations which can settle this problem. Therefore there is an extra legem gap in the law. This issue was examined many times by the authors of legal literature and the Supreme Court, who released two judicial decisions in this case between 1990-1992, representing two different points of view. The resulting state of affairs caused debate as to the validity of The Supreme Court's rulings. This has also contributed to instilling doubts in employers and employees about how to interpret the law correctly without exposing yourself to a risk of trial. Due to this issue being connected with such an important subject as the rights of employees to their benefits regarding termination of employment contract, the legislator is obliged to solve this problem by introducing appropriate legal regulations. Successfully implementing an effective solution would eliminate a serious legal gap from the Polish law.

\section{Wstęp}

Rozwiązanie umowy o pracę, zawartej na czas określony lub nieokreślony, w trybie ustawy z dnia 13 marca 2003 r. o szczególnych zasadach rozwiązywania z pracownikami stosunków pracy z przyczyn niedotyczących pracowników (t.j. Dz. U. z 2018 r., poz. 844 z późn. zm.), nazywanej też „ustawą o zwolnieniach grupowych”, stanowi jej zakończenie na specjalnych zasadach. Najogólniej rzecz ujmując, pracodawca odwołuje się do takich narzędzi prawnych w sytuacjach trudnych, gdy dotykają go poważne problemy natury ekonomicznej bądź konieczne jest zakończenie jego działalności poprzez ogłoszenie upadłości czy likwidacji. Skorzystanie z procedury zwolnień grupowych ma, co do zasady, miejsce, gdy zastosowanie innych środków jest niecelowe lub niemożliwe (Frączek, Jaroszewska-Ignatowska 2013: 79-80; Jaroszewska-Ignatowska, Spytek-Bandurska 2005: 354). Podstawę prawidłowego i zgodnego z prawem jej przeprowadzenia stanowią przepisy ustawy z dnia 26 czerwca 1974 r. Kodeks pracy (t.j. Dz. U. z 2018 r., poz. 917 z późn. zm.) oraz wskazanego w zdaniu poprzednim aktu normatywnego. 
Celem poniższych rozważań jest przedstawienie jednego z poważniejszych problemów pojawiających się przy koincydencyjnym stosowaniu przepisów tych dwóch ustaw. Polega on na ustaleniu finalnego momentu trwania stosunku pracy, a w konsekwencji również wysokości odprawy z art. 8 ustawy o zwolnieniach grupowych, w sytuacji gdy przy wypowiedzeniu umowy o pracę zastosowano skrócony okres wypowiedzenia z art. $36^{1}$ ustawy Kodeks pracy, a jednocześnie w okresie, o który skrócono wypowiedzenie, pracownikowi upłynęły 2 lub 8 lat zakładowego stażu pracy. W obowiązujących przepisach próżno szukać rozwiązania tej kwestii i jednoznacznego określenia terminu zakończenia stosunku pracy. Polski ustawodawca nie wprowadził w tym zakresie stosownych regulacji. Dlatego zasadne jest postawienie tezy, iż mamy tu do czynienia z luką prawną extra legem, czyli przypadkiem, gdy dla danego stanu faktycznego brak jest normy prawnej (Muras 2017: 49; Nowacki, Tobor 2016: 267; Nowacki 2003: 346-350; Koszowski 2013: 111). Taka okoliczność nie sprzyja budowaniu autorytetu prawodawcy i zaufania do Państwa oraz pewności ustanawianych w jego imieniu regulacji. Choć pamiętać należy, że nie ma możliwości, aby systemy prawa normowały wszystkie stosunki społeczne, to jednak w dziedzinie tak ważnej jak uprawnienia pracownicze, w szczególności te o charakterze finansowym, ustawodawca powinien zabrać głos. W relacji pracownik - pracodawca zatrudniony zawsze będzie stroną słabszą ekonomicznie, której pozycja musi zostać wyrównana z pomocą obowiązujących przepisów. To właśnie dobrze skonstruowane prawo stanowi gwarancję praw pracowniczych.

O wadze przedstawianego w niniejszym artykule zagadnienia świadczyć może fakt, że kilkakrotnie było ono przedmiotem orzeczeń Sądu Najwyższego. W przeciągu krótkiego czasu, bo nieco ponad dwóch lat, podjął on dwie uchwały prezentujące przeciwstawne poglądy w tej materii. Mowa tu o uchwale z dnia 23 kwietnia 1990 r. (III PZP 3/90) oraz o uchwale z dnia 9 lipca 1992 r. (I PZP 20/92). Dwoistość orzecznictwa spowodowała, że pojawiły się rozbieżności i uzasadnione wątpliwości co do tego, które ze wskazanych przez Sąd Najwyższy rozwiązań jest prawidłowe i powinno być powszechnie stosowane. Przyczyniło się to również do utrwalenia wśród pracodawców i pracowników wątpliwości, jak interpretować przepisy, aby w takiej sytuacji nie narazić się na czasochłonny i kosztowny spór sądowy. Oczywiście każda ze stron rozwiązywanego stosunku pracy powoływać się będzie na pogląd dla siebie korzystny, wsparty w tym przypadku autorytetem Sądu Najwyższego. Jednak do czasu prawomocnego rozstrzygnięcia każdego indywidualnego sporu przez sąd pracy żaden z jego uczestników nie będzie miał pewności, czy przedstawione stanowisko zostanie uznane za prawidłowe oraz czy obowiązek wypłaty świadczenia bądź jego odmowa zostaną prawnie usankcjonowane.

Przedstawiane zagadnienie dotyczy niezwykle istotnego tematu, jakim są świadczenia związane z zakończeniem stosunku pracy, a konkretnie wysokość odprawy, o której mowa w art. 8 ustawy o zwolnieniach grupowych, wypłacanej w opisanych tu okolicznościach. Ze względu na jego wagę ustawodawca powinien szczególnie 
zadbać o wyeliminowanie wszelkich towarzyszących wątpliwości i luk prawnych. Taka jego powinność wynika wprost z § 2 rozporządzenia Prezesa Rady Ministrów z dnia 20 czerwca 2002 r. w sprawie „Zasad techniki prawodawczej” (t.j. Dz. U. z 2016 r., poz. 283). Zgodnie z zawartymi tam wytycznymi ustawa musi w sposób wyczerpujący regulować daną dziedzinę spraw i nie może pozostawiać poza zakresem swego unormowania istotnych jej fragmentów. Tymczasem na skutek braku regulacji obowiązek ten, w omawianym przypadku, pozostaje niespełniony.

\section{Skrócenie okresu wypowiedzenia w oparciu o art. $36^{1}$ ustawy Kodeks pracy - krótka charakterystyka}

Na wstępie analizy problemu dotyczącego określenia momentu ustania stosunku pracy, gdy zastosowano skrócony okres wypowiedzenia, konieczne jest omówienie regulacji art. 36' § 1 ustawy Kodeks pracy. Przewiduje on możliwość zastosowania przez pracodawcę takiego okresu wypowiedzenia wyłącznie w sytuacji, gdy wypowiedzenie pracownikowi umowy o pracę zawartej na czas określony lub na czas nieokreślony następuje z powodu ogłoszenia upadłości lub likwidacji pracodawcy albo z innych przyczyn niedotyczących pracowników. Pracodawca może wówczas, w celu wcześniejszego zakończenia umowy o pracę, skrócić okres trzymiesięcznego wypowiedzenia, najwyżej jednak do jednego miesiąca. W takim przypadku za część okresu wypowiedzenia, o którą uległ on skróceniu, pracownikowi przysługiwać będzie odszkodowanie w wysokości wynagrodzenia, jakie osiągnąłby w tym czasie.

Zastosowanie tej instytucji jest fakultatywne i nie zmienia trybu rozwiązania umowy o pracę. Opcja ta dotyczy skrócenia tylko trzymiesięcznego okresu wypowiedzenia i nie obejmuje przypadków, gdy taki zabieg zastosowano w oparciu o porozumienie stron, choćby jego inicjatorem był pracodawca (Baran 2013: 225). Jest to jednostronna decyzja zatrudniającego, a ustawa Kodeks pracy nie przewiduje konieczności uzyskania na to zgody pracownika i uznaje takie oświadczenie woli za w pełni skuteczne i wystarczające. Pamiętać jednak trzeba, że poinformowanie zatrudnionego o zastosowaniu wobec niego krótszego okresu wypowiedzenia musi nastąpić w tym samym momencie, w którym pracodawca przekazuje mu oświadczenie o rozwiązaniu umowy o pracę (Walczak, Wojewódka 2017: 123). Niektórzy autorzy przyjmują, że decyzja przełożonego powinna być zawarta w piśmie wypowiadającym (Wratny 2016: 128). Rzeczywiście takie rozwiązanie stosowane jest najczęściej, ze względu na jego praktyczny wymiar. Jednak przepis nie statuuje wprost takiego obowiązku, i w zasadzie brak prawnych przeciwwskazań, aby skrócenie okresu wypowiedzenia nastąpiło w osobnym piśmie, przekazanym pracownikowi jednocześnie z oświadczeniem o rozwiązaniu umowy o pracę. Gdyby informacja nie została przekazana w tym konkretnym momencie, skrócenie okresu wypowiedzenia nie będzie skuteczne (wyrok SN z 19.12.1990; Mitrus 2010: 9). 
Katalog przyczyn, które uzasadniają zastosowanie krótszego okresu wypowiedzenia, został w przepisie zakreślony dość wąsko. Wymieniono tam tylko trzy powody, które mogą stanowić podstawę takiego działania podmiotu zatrudniającego. Są to: ogłoszenie upadłości, likwidacja pracodawcy oraz inne przyczyny niedotyczące pracowników. Wyliczenie ma charakter zamknięty i wyszczególnia okoliczności, gdy pracodawca nie jest w stanie zapewnić pracy, z racji przeprowadzanej u niego restrukturyzacji, ogłoszenia upadłości bądź zakończenia działalności (likwidacji) (Świątkowski 2016: 238). Sposób ich sformułowania ujawnia, iż dotyczą one w dużej mierze zwolnień przeprowadzanych w trybie ustawy o szczególnych zasadach rozwiązywania z pracownikami stosunków pracy z przyczyn niedotyczących pracowników (Muszalski 2013: 84). Ustawa ta w art. 1 ust. 1 stanowi, że jej przepisy stosuje się w razie konieczności rozwiązania przez pracodawcę zatrudniającego co najmniej 20 pracowników stosunków pracy z przyczyn niedotyczących pracowników, a więc wymienia ten sam powód co art. $36^{1} \S 1$ ustawy Kodeks pracy. W tym miejscu należy nadmienić, iż ustawa o zwolnieniach grupowych klasyfikuje również ogłoszenie upadłości oraz likwidację pracodawcy jako przyczyny rozwiązania umowy o pracę niedotyczące pracowników, co wynika z brzmienia jej art. 7.

W treści art. $36^{1} \S 1$ ustawy Kodeks pracy jako jedną z podstaw do zastosowania skróconego okresu wypowiedzenia wymieniono „inne przyczyny niedotyczące pracowników". O ile interpretacja pozostałych dwóch okoliczności nie budzi wątpliwości, o tyle tak ogólne i pojemne sformułowanie wymaga dalszych wyjaśnień (Sobczyk 2005: 30). Przede wszystkim podkreślić trzeba, że powody te nie muszą być wskazane ani doprecyzowane w odrębnych przepisach (Świątkowski 2018: 244). Ustawodawca celowo użył niedookreślonego zwrotu, który pozwala przyporządkować tu wiele czynników o odmiennym charakterze, odnoszących się do rozmaitych dziedzin działalności pracodawcy. Taki zabieg pozwala na zastosowanie omawianego przepisu w przypadku różnych problemów towarzyszących funkcjonowaniu podmiotu zatrudniającego.

Jako przyczyny wypowiedzenia umów o pracę niedotyczące pracowników z pewnością wskazać można okoliczności, które nie są związane z osobistymi przymiotami pracownika lub sposobem wykonywania przez niego pracy (Jaśkowski, Maniewska, Stelina 2007: 27). Będą to wszelkie względy związane z pracodawcą, przy czym w związku $z$ brakiem sprecyzowania przez ustawodawcę $w$ treści przepisu ich rodzaju trzeba tu wziąć pod uwagę zarówno powody bezpośrednio, jak i pośrednio związane z pracodawcą, a także przyczyny o charakterze wewnętrznym bądź zewnętrznym, występujące trwale, okresowo lub jednorazowo, istotne lub całkowicie poboczne, zawinione przez zatrudniającego albo też powstałe bez jego winy (Rylski 2016: 47). Legislator próbował już wcześniej, na gruncie przepisów poprzednio obowiązującej ustawy z dnia 28 grudnia 1989 r. o szczególnych zasadach rozwiązywania z pracownikami stosunków pracy z przyczyn dotyczących zakładu pracy (Dz. U. z 1990 r. Nr 4, poz. 19 z późn. zm.), pogrupować te czynniki w wyodrębnione kategorie. W art. 1 ust. 1 wskazanego aktu normatywnego wymieniono przyczyny ekonomiczne oraz organizacyjne, produkcyjne 
i technologiczne. Wyliczenie to, mimo iż zostało usunięte z tekstu nowej ustawy o zwolnieniach grupowych, może być pomocne, ze względu na swój uniwersalny charakter, przy interpretacji zwrotu „inne przyczyny niedotyczące pracowników", również w aktualnym stanie prawnym. Do przesłanek ekonomicznych włączyć należy wszelkie okoliczności związane z finansowym aspektem działalności pracodawcy, a przede wszystkim z brakiem środków pieniężnych i koniecznością szukania oszczędności. Jak wskazuje dotychczasowe orzecznictwo, „przyczyny ekonomiczne (...) to takie przyczyny, nieodłącznie związane lub bezpośrednio wynikające z niedoboru środków finansowych na podstawową sferę działalności pracodawcy, które w prosty sposób prowadzą do ograniczenia zatrudnienia przy określonym rodzaju pracy poprzez likwidację stanowiska pracy" (wyrok SA w Gdańsku z 5.06.2013, III AUa 1246/13). Z kolei pobudki organizacyjne oznaczać będą wszelkie sytuacje, gdy dochodzi do zmian strukturalnych u pracodawcy. Przykładem są tu procesy polegające na łączeniu się, dzieleniu czy też likwidacji jednostek organizacyjnych, odbywające się w ramach podmiotu. Czynniki produkcyjne związane są z całokształtem działań, zarówno bieżących, jak i dopiero planowanych, w zakresie produkcji odbywającej się u pracodawcy. Mogą one polegać na konieczności dostosowania procesów wytwórczych do nowych przepisów prawa lub dynamicznie zmieniających się realiów rynkowych. Powody technologiczne z kolei będą ściśle związane z modyfikacjami w zakresie wykorzystywanych przez zatrudniającego technologii. Jak więc wynika z powyższego, przyczyn skrócenia okresu wypowiedzenia niedotyczących pracowników może być bardzo wiele, a opracowanie ich wyczerpującego katalogu jest niewykonalne. Spowodowane to jest przede wszystkim nieskończoną liczbą możliwości, wynikających chociażby ze złożonego charakteru współczesnej gospodarki i funkcjonujących w niej podmiotów (Krysińska-Wnuk 2009: 187).

Uzupełnieniem omawianej regulacji art. $36^{1} \S 1$ ustawy Kodeks pracy jest § 2, stanowiący, że okres, za który przysługuje odszkodowanie, wlicza się pracownikowi pozostającemu w tym czasie bez pracy do okresu zatrudnienia. Wprowadza on obowiązek wypłaty świadczenia będącego surogatem wynagrodzenia za pracę, co ma zrekompensować etatowcowi szkodę, jaką poniósł w wyniku braku świadczenia pracy w czasie, o jaki nastąpiło skrócenie wypowiedzenia (Florek 2017: 279). Konsekwencją zastosowania art. $36^{1}$ ustawy Kodeks pracy jest przecież nieuzyskanie przez pracownika wynagrodzenia za czas, który trwać może nawet dwa miesiące, a więc powstanie wymiernego uszczerbku w jego majątku, tym dotkliwsze, że pojawia się w momencie utraty zatrudnienia (wyrok SA w Katowicach z 20.02.1990, III APr 5/91). W przepisie zaznaczono także, iż czas, o który skraca się okres wypowiedzenia, wliczony zostaje do okresu zatrudnienia pracownikowi, pozostającemu wówczas bez pracy. Nie wskazano jednak wprost, która data traktowana jest jako definitywnie kończąca byt stosunku pracy. Nie wiadomo zatem, czy traktować tak datę upływu skróconego okresu, czy też datę, w której upłynąłby okres wypowiedzenia, gdyby nie został skrócony. Brak w tym zakresie jednoznacznej decyzji ustawodawcy, która znalazłaby swoje odzwierciedlenie w obowiązujących przepisach. Stanowi to spore utrudnienie w wykładni i stosowaniu art. $36^{1}$ ustawy Kodeks pracy. 


\section{Charakter odprawy z art. 8 ustawy o szczególnych zasadach rozwiązywania z pracownikami stosunków pracy z przyczyn niedotyczących pracowników}

Jak już wyżej zasygnalizowano, zastosowanie art. $36^{1}$ ustawy Kodeks pracy, w razie przeprowadzania procedury zwolnień grupowych, musi być skorelowane $z$ innymi obowiązującymi przepisami. Szczególną rolę odgrywa tu art. 8 ustawy z dnia 13 marca 2003 r. o szczególnych zasadach rozwiązywania z pracownikami stosunków pracy z przyczyn niedotyczących pracowników. Przepis ten określa wysokość odprawy pieniężnej przysługującej pracownikowi przy rozwiązaniu z nim umowy o pracę w tym szczególnym trybie. Stanowi on podstawę prawną dla jednego z bardziej znaczących uprawnień przysługujących pracownikom w takich okolicznościach. Pamiętać należy, że legitymacja do otrzymania świadczenia z art. 8 jest w pełni niezależna od prawa do odszkodowania z art. $36^{1}$ ustawy Kodeks pracy. O ile bowiem odszkodowanie przysługiwać będzie wszystkim pracownikom, którym skrócono okres wypowiedzenia, o tyle wspomniana odprawa wypłacona zostanie wyłącznie tym, wobec których zastosowano ustawę o zwolnieniach grupowych, a dodatkowo ich pracodawcy zatrudniają minimum 20 osób (Mitrus 2010: 9).

Odprawa pieniężna, o której mowa w art. 8 ustawy o zwolnieniach grupowych, jest szczególnym uprawnieniem o charakterze finansowym. Jest to świadczenie majątkowe, wypłacane jednorazowo, którego głównym celem jest chociażby częściowe zrekompensowanie pracownikom uszczerbku majątkowego poniesionego w związku z utratą pracy (Rylski 2016: 217; Walorska 2014: 155). W piśmiennictwie utrwalił się pogląd, że przedmiotowa odprawa nie jest wynagrodzeniem, odszkodowaniem ani nawet świadczeniem socjalnym. Jej charakter jest specyficzny, co związane jest też ze szczególną sytuacją, w której jest wypłacana (Latos-Miłkowska, Pisarczyk 2005: 142-143; Rylski 2016: 218; Krysińska-Wnuk 2009: 148). Otrzymywać ją będą zarówno etatowcy, zwalniani w trybie indywidualnym, na podstawie art. 10 ustawy o zwolnieniach grupowych, jak i ci, których stosunki pracy rozwiązywane będą w trybie grupowym. Przy czym przesłanką kwalifikującą do otrzymania świadczenia będzie sam fakt rozwiązania przez pracodawcę umowy o pracę w trybie ustawy z dnia 13 marca $2003 \mathrm{r}$. Wypłata powinna więc nastąpić z upływem ostatniego dnia trwania stosunku pracy, gdyż od tego momentu świadczenie staje się wymagalne (Walorska 2014: 155). Pracodawca nie będzie mógł jej otrzymania uzależnić od tego, czy dany pracownik od razu zostanie zatrudniony w nowym miejscu, czy będzie pozostawał bez pracy i przez jak długi czas, czy w ogóle będzie poszukiwał nowego zatrudnienia.

Artykuł 8 ustawy z dnia 13 marca 2003 r. określa wysokość należnego świadczenia. Ustawodawca uzależniłją od dwóch czynników: zakładowego stażu pracy oraz kwoty wynagrodzenia uzyskiwanego przez pracownika. Zgodnie z treścią przepisu w związku z rozwiązaniem stosunku pracy w ramach grupowego zwolnienia przysługuje odprawa pieniężna w wysokości jednomiesięcznego wynagrodzenia, jeżeli pracownik 
zatrudniony był u danego pracodawcy krócej niż 2 lata. Jeśli natomiast zatrudnienie trwało od 2 do 8 lat, wówczas wysokość odprawy będzie równa dwumiesięcznemu wynagrodzeniu. $Z$ kolei gdy zatrudnienie u danego pracodawcy trwało ponad 8 lat, otrzyma on odprawę stanowiącą równowartość trzymiesięcznego wynagrodzenia. Ustawodawca określił maksymalną wysokość omawianego świadczenia na poziomie 15-krotności minimalnego wynagrodzenia za pracę, ustalanego na podstawie odrębnych przepisów, obowiązującego $\mathrm{w}$ dniu rozwiązania stosunku pracy.

Zakładowy staż pracy to jedno z podstawowych pojęć koniecznych do zrozumienia istoty omawianego zagadnienia. Należy przez nie rozumieć okres trwania stosunku pracy pracownika z jednym pracodawcą (Rączka 2002: 4; Florek 1980: 81). Prawidłowe ustalenie długości tej więzi będzie miało decydujące znaczenie dla wysokości odprawy. Z pewnością w oparciu o treść art. 8 można stwierdzić, że na zakładowy staż pracy składa się cały okres zatrudnienia danego pracownika, aż do ostatniego dnia, mimo iż nie zostało to $w$ nim wprost wyrażone. Poza tym $w$ art. 8 § 2 ustawy $z$ dnia 13 marca 2003 r. zawarto postanowienie, będące wskazówką, jakie okresy zatrudnienia wlicza się do stażu pracy u jednego pracodawcy. Wyraźnie wyartykułowano tam, że odpowiednie zastosowanie znajdzie tu art. $36 \S 1^{1}$ ustawy Kodeks pracy, stwierdzający, że do tego okresu musi zostać zaliczony czas zatrudnienia u poprzedniego pracodawcy, który jest następcą prawnym aktualnego pracodawcy. Obejmuje on sytuacje, gdy zmiana po stronie podmiotu zatrudniającego nastąpiła na zasadach określonych w art. $23^{1}$ ustawy Kodeks pracy, a także gdy z mocy odrębnych przepisów nowy pracodawca jest następcą prawnym w stosunkach pracy, nawiązanych przez swojego poprzednika (Wrońska-Zblewska 2012: 341; Walorska 2014: 79). Brak tam natomiast unormowań precyzujących, jak pracodawca ma obliczyć długość zakładowego stażu pracy w przypadku skrócenia okresu wypowiedzenia.

\section{Moment ustania stosunku pracy w sytuacji skrócenia okresu wypowiedzenia}

Powyżej zasygnalizowano, że moment ustania stosunku pracy w przypadku zastosowania skróconego okresu wypowiedzenia nie został wskazany przez ustawodawcę w żadnych obowiązujących przepisach. Art. $36^{1} \S 2$ ustawy Kodeks pracy wyraźnie stanowi jedynie o tym, że czas, o który okres wypowiedzenia został skrócony, wlicza się pracownikowi, który w tym czasie pozostaje bez pracy, do okresu zatrudnienia. Określa go więc jako tzw. okres zaliczalny, to jest czas pozostawania poza stosunkiem pracy, który na mocy konkretnej regulacji wliczany jest do okresu zatrudnienia. Zdaniem wielu autorów włączenie czasu, gdy praca nie była świadczona, do stażu pracy lub do zakładowego stażu pracy nastąpić może tylko wyjątkowo, w oparciu o wyraźną regulację ustawową (Jaśkowski, Maniewska, Stelina 2007: 113; Rączka 2002: 2; Rylski 2016: 230; Walorska 2013: 299). Stanowisko to jest spójne również z ogólną zasadą, iż uprawnienie do świadczenia nie może mieć charakteru domyślnego i musi wynikać 
wprost z konkretnego przepisu. Skoro zatem pogląd ten wydaje się oczywisty, warto rozważyć, dlaczego Sąd Najwyższy podjął w tej materii dwie uchwały prezentujące odmienne stanowiska.

Pierwsza z nich to uchwała 7 sędziów Sądu Najwyższego z dnia 23 kwietnia 1990 r., W sprawie III PZP 3/90. W jej uzasadnieniu przyjęto, iż „okres, o jaki skrócono wypowiedzenie umowy o pracę (art. $36^{1} \S 1$ k.p.), za który pracownikowi przysługuje odszkodowanie, wlicza się do okresu zatrudnienia w zakładzie pracy, zobowiązanym do wypłaty odszkodowania, jeżeli w tym okresie pracownik pozostawał bez pracy". W konsekwencji takiego stanowiska również odprawa z art. 8, w sytuacji gdyby podczas skróconego wypowiedzenia upływał sporny czas 2 lub 8 lat zakładowego stażu pracy, przysługiwałaby pracownikowi w wymiarze wyższym. Byłoby to spowodowane wliczeniem do zatrudnienia czasu, o jaki skrócono okres wypowiedzenia. Jak widać, Sąd Najwyższy powyższą uchwałą wprost wyraził stanowisko korzystne dla pracowników. Zostało ono jednak krytycznie ocenione w literaturze (Rączka 1991: 61; Wagner 1991: 94-95), gdzie zakwestionowano argumentację, jaką posłużył się sąd w uzasadnieniu. Nieco ponad dwa lata później, dnia 9 lipca 1992 r., Sąd Najwyższy podjął uchwałę w składzie 7 sędziów, w sprawie I PZP 20/92, w której wyraził odmienny pogląd odnośnie do omawianej kwestii. Stwierdził, iż datą ustania stosunku pracy jest dzień upływu skróconego okresu wypowiedzenia. Sformułował tu stanowisko niekorzystne dla pracowników, zgodnie z którym zastosowanie przez pracodawcę krótszego okresu wypowiedzenia powoduje rozwiązanie tej umowy w momencie zakończenia jego biegu. Oznacza to, iż w chwili wypłaty odszkodowania stosunek pracy już nie wiąże stron, a pracownik nie nabywa w tym czasie prawa do urlopu wypoczynkowego, zaś odszkodowanie za okres wypowiedzenia nie jest wynagrodzeniem w rozumieniu art. 78 i nast. ustawy Kodeks pracy. Od tego świadczenia nie odprowadza się też składki z tytułu ubezpieczenia pracownika. Nadto Sąd Najwyższy zaznaczył, że datę upływu tego skróconego okresu podaje się w świadectwie pracy jako datę zakończenia stosunku pracy. W sytuacji zatem gdy pracodawca skorzysta $z$ uprawnienia przewidzianego $\mathrm{w}$ art. $36^{1}$ ustawy Kodeks pracy, umowa o pracę rozwiąże się wcześniej, niż wskazywałby ustawowy okres wypowiedzenia przewidziany w art. 36 ustawy Kodeks pracy (Sobczyk 2014: 168).

Stanowisko z uchwały w sprawie I PZP 20/92 znajduje swoje potwierdzenie w wyroku Sądu Najwyższego z dnia 10 października 1990 r. (I PR 297/90) oraz w postanowieniu Sądu Najwyższego z dnia 9 maja 2006 r. (II PZP 2/06). Pierwsze z przywołanych orzeczeń wydane zostało jeszcze na gruncie ustawy z dnia 28 grudnia 1989 r. o szczególnych zasadach rozwiązywania z pracownikami stosunków pracy z przyczyn dotyczących zakładu pracy, jednak mimo to częściowo zachowało aktualność. W uzasadnieniu sąd precyzyjnie wskazał moment ustania stosunku pracy w przypadku zastosowania skróconego okresu wypowiedzenia. Argumentował, że skoro z woli stron następuje skrócenie okresu wypowiedzenia, to roszczenie o odprawę z art. 8 powstaje $w$ dacie, którą wskazano jako dzień rozwiązania stosunku pracy na mocy czynności prawnej skracającej okres wypowiedzenia (art. $36 \S 6$ ustawy Kodeks pracy). Uprawnienie do 
otrzymania odprawy powstaje bowiem w momencie rozwiązania stosunku pracy, a nie w chwili, w której miał się kończyć bieg okresu wypowiedzenia. Z kolei w uzasadnieniu postanowienia wydanego w sprawie II PZP 2/06 zaakcentowano fakt, że gdyby stosunek pracy trwał mimo upływu skróconego okresu wypowiedzenia, pracownik zachowałby prawo do wynagrodzenia za pracę świadczoną lub za czas gotowości do pracy, przy istnieniu przeszkód w jej wykonywaniu ze strony pracodawcy. Konsekwencją byłaby możliwość skutecznego dochodzenia przez zatrudnionego stosownych kwot przed sądem pracy. Tymczasem przewidziane w art. $36^{1} \S 2$ k.p. świadczenie stanowi swego rodzaju rekompensatę za utracone wynagrodzenie, wobec skrócenia czasu pozostawania w stosunku pracy. Sąd Najwyższy zwrócił także uwagę, iż art. $36^{1}$ § 2 k.p. ustanawia okres zaliczalny do okresów zatrudnienia. Jest to okres, w czasie którego stosunek pracy nie istnieje, ale z mocy wyraźnej regulacji ustawowej, układów zbiorowych pracy czy zakładowych porozumień płacowych jest wliczany do okresu zatrudnienia. W takim okresie pracownik nie może nabyć takich uprawnień, jak prawo do urlopu wypoczynkowego czy do nagrody jubileuszowej.

Oba przedstawione powyżej stanowiska opierają się wyłącznie na orzeczeniach Sądu Najwyższego oraz opiniach wyrażonych w piśmiennictwie. Co prawda drugi z poglądów, oparty na uchwale I PZP 20/92, zyskał zarówno wśród przedstawicieli nauki prawa, jak i w orzecznictwie niemalże powszechną aprobatę, jednak brakuje normatywnych rozwiązań pozwalających jednoznacznie wskazać moment, w którym dobiega końca czas trwania zakładowego stażu pracy wspomnianego w art. 8. Trzeba też wziąć pod uwagę, że pracownicy to zwykle osoby niezorientowane w zawiłych rozważaniach doktryny prawa pracy i aktualnych tendencjach orzeczniczych. Często, stojąc w obliczu utraty zatrudnienia, decydują się na kierowanie roszczeń do sądów pracy, gdyż mają nadzieję na uzyskanie jakichkolwiek dodatkowych środków. Dlatego właśnie wyraźne określenie, który moment jest tym kończącym stosunek pracy, powinno zostać wprowadzone do obowiązujących przepisów. Ma to tym większe znaczenie, że sprecyzowanie chwili zakończenia stosunku pracy rzutuje w wielu przypadkach na uprawnienia pracownicze, w tym te legitymujące do otrzymania konkretnych świadczeń.

\section{Zakończenie}

Z powyższych rozważań wynika, że żaden z obowiązujących przepisów nie zawiera regulacji mogącej znaleźć zastosowanie do omawianego problemu. Dlatego też należy stwierdzić istnienie luki prawnej extra legem (Koszowski 2013: 111). O wystąpieniu tego rodzaju luki decyduje właśnie brak normy prawnej, którą można zastosować do konkretnego stanu faktycznego. Jednocześnie podkreślić trzeba, iż deficyt regulacji jest tu niezwykle kłopotliwy. Jego efektem jest nieuporządkowany stan prawny, a najbardziej widoczne i negatywne jego konsekwencje to liczne pozwy pracowników nieznajdujących rozwiązania swojego problemu w obowiązujących przepisach oraz sprzeczne i niejednolite orzecznictwo. Ustawodawca nie sformułował przepisów, 
które pomogłyby w jednoznacznym określeniu, kiedy następuje skutek w postaci rozwiązania stosunku pracy, gdy zastosowany zostaje skrócony okres wypowiedzenia. Rozstrzygnięcie tego zagadnienia miało i nadal ma duże znaczenie dla wielu kwestii prawnych związanych z zakończeniem stosunku pracy. Szczególnie istotne jest to właśnie w sytuacji, gdy w okresie skróconego okresu wypowiedzenia upłynęły dwa lub osiem lat zakładowego stażu pracy.

Analiza poglądów doktryny oraz orzecznictwa, odnoszących się do omawianego problemu, wskazuje na przewagę stanowiska, zgodnie z którym stosunek pracy kończy się z momentem upływu skróconego wypowiedzenia. Nadal jednak pojawiają się wątpliwości co do wskazania podstawy prawnej dla jego uargumentowania. Próbę wypracowania rozwiązania i wypełnienia istniejącej w przepisach luki podjął Sąd Najwyższy, co dowodzi zarówno rangi zagadnienia, jak i znacznej częstotliwości jego występowania w praktyce. Uchwały podjęte przez ten sąd w latach 1990-1992 prezentują jednak dwa wykluczające się stanowiska. Potęguje to tylko stan niepewności prawnej i w wielu przypadkach prowadzi do wszczynania procesów sądowych, których przy precyzyjnej legislacji można by uniknąć.

Polskie prawo pracy wiele uprawnień, w tym te legitymujące do otrzymania przez pracownika konkretnych świadczeń pieniężnych, uzależnia od długości stażu pracy lub zakładowego stażu pracy (Rączka 2002: 5). Tym bardziej więc dziwi brak przepisów normujących prezentowane zagadnienie. Nie sposób bowiem uznać za wystarczające rozwiązanie oraz za skuteczne wypełnienie luki prawnej uchwał Sądu Najwyższego, w szczególności tych, które zapadły w sprawach oznaczonych sygnaturami III PZP 3/90 i I PZP 20/92. Zawarte w nich odmienne rozstrzygnięcia sprzyjają stosowaniu niejednolitych rozwiązań do podobnych lub nawet identycznych stanów faktycznych. Przy czym w każdym przypadku, niezależnie od prezentowanego stanowiska, strona stosunku pracy lub sąd orzekający w sprawie może powołać się na autorytet Sądu Najwyższego i korzystne dla siebie orzeczenie. Nadto nie można pominąć faktu, że żadne z wymienionych orzeczeń nie zostało wpisane do księgi zasad prawnych, dlatego też brak ostatecznych argumentów pozwalających uzasadnić, które stanowisko, w świetle brzmienia obowiązujących przepisów, należy uznać za wiodące. Pamiętać trzeba, że orzeczenia sądów powszechnych oraz Sądu Najwyższego w polskim systemie prawnym nie mają statusu regulacji prawnych równych ustawom. Tym niemniej docenienia wymaga pomocnicza rola orzecznictwa i doktryny w wypracowaniu prawnych rozwiązań omawianego zagadnienia.

Mimo iż przedstawiony stan prawny trwa już długie lata, ustawodawca nadal nie uznał za zasadne wprowadzenia regulacji wprost rozstrzygającej kwestię, kiedy w sytuacji zastosowania skróconego okresu wypowiedzenia stosunek pracy kończy swój byt. Tymczasem zaproponowanie konkretnych rozwiązań w tym zakresie leży w interesie zarówno pracowników, jak i pracodawców. Unormowanie ustawowe położyłoby kres powstającym na tym tle sporom i wzmocniłoby zaufanie obywateli do prawodawcy i stanowionego prawa. Dodatkowo przyczyniłoby się do ujednolicenia stosowanych 
rozwiązań prawnych, a także doprowadziłoby do zmniejszenia liczby sporów sądowych dotyczących tej materii, co w sytuacji przeciążenia polskich sądów jest nie do przecenienia. Z tego też względu postulat de lege ferenda wprowadzenia zmian w obowiązującym prawie jawi się jako w pełni uzasadniony i konieczny. Przemawiają za nim zarówno argumenty natury prawnej, jak i społecznej oraz finansowej. Poza tym w ten sposób z polskiego systemu prawnego zostałaby skutecznie usunięta kolejna luka, a poczucie pewności prawa wśród ogółu obywateli uległoby wzmocnieniu.

\section{Bibliografia}

\section{Literatura:}

Baran K.W. (red.), 2013, Prawo pracy i ubezpieczeń społecznych, Warszawa.

Florek L., 1980, Staż pracy, Warszawa.

Florek L. (red.), 2017, Kodeks pracy. Komentarz, Warszawa.

Frączek M., Jaroszewska-Ignatowska I., 2013, Zwolnienia pracowników. Praktyczny komentarz, Warszawa.

Jaroszewska-Ignatowska I., Spytek-Bandurska G., 2005, Zatrudnianie i zwalnianie pracowników, Warszawa.

Jaśkowski K., Maniewska E., Stelina J., 2007, Grupowe zwolnienia. Komentarz, Warszawa.

Koszowski M., 2013, O lukach w prawie rzadko spotykanych słów kilka, „Archiwum Filozofii Prawa i Filozofii Społecznej", nr 1.

Krysińska-Wnuk L., 2009, Regulacja zwolnień grupowych pracowników, Warszawa.

Latos-Miłkowska M., PisarczykŁ., 2005, Zwolnienia z przyczyn niedotyczących pracownika, Warszawa. Mitrus L., 2010, Sytuacja pracownika w okresie wypowiedzenia umowy o pracę „PPraca i Zabezpieczenie Społeczne", nr 7.

Muras Z., 2017, Podstawy prawa, Warszawa.

Muszalski W. (red.), 2013, Kodeks pracy. Komentarz, Warszawa.

Nowacki J., 2003, Studia z teorii prawa, Kraków.

Nowacki J., Tobor Z., 2016, Wstęp do prawoznawstwa, Warszawa.

Rączka K., 1991, Glosa do uchwała 7 sędziów Sądu Najwyższego z dnia 23 kwietnia 1990 r., nr III PZP 3/90 „"Praca i Zabezpieczenie Społeczne”, nr 7.

Rączka K., 2002, Staż pracy [w:] L. Florek, Encyklopedia prawa pracy i ubezpieczeń społecznych - komentarz do instytucji prawnych, Warszawa.

Rylski M., 2016, Zwolnienia grupowe. Komentarz do ustawy, Warszawa.

Sobczyk A., 2005, Uwagi do ustawy o zwolnieniach grupowych, „Praca i Zabezpieczenie Społeczne”, nr 10.

Świątkowski A., 2016, Kodeks pracy. Komentarz, Warszawa.

Wagner B., 1991, Glosa do Uchwały Składu Siedmiu Sędziów Sądu Najwyższego Izba Administracyjna, Pracy i Ubezpieczeń Społecznych z dnia 23 kwietnia 1990 r. III PZP 3/90, "Orzecznictwo Sądów Polskich", nr 2.

Walczak K., Wojewódka M. (red.), 2017, Prawo pracy dla sędziów i pełnomocników, Warszawa. 
Walorska P., 2013, Okresy zaliczalne do stażu pracy, "Monitor Prawa Pracy”, nr 6.

Walorska P., 2014, Staż pracy, Warszawa.

Wratny J., 2016, Kodeks pracy. Komentarz, Warszawa.

Wrońska-Zblewska K., 2012, Ustawa o szczególnych zasadach rozwiqzzywania z pracownikami stosunków pracy z przyczyn niedotyczących pracowników [w:] J. Ziarno (red.), Zwalnianie pracowników. Wyjaśnienia, porady, orzecznictwo i wzory, Warszawa.

\section{Akty normatywne:}

Ustawa z dnia 26 czerwca 1974 r. Kodeks pracy, t.j. Dz. U. z 2018 r., poz. 917 z późn. zm.

Ustawa z dnia 28 grudnia 1989 r. o szczególnych zasadach rozwiązywania z pracownikami stosunków pracy z przyczyn dotyczących zakładu pracy, Dz. U. z 1990 r. Nr 4, poz. 19 z późn. zm.

Rozporządzenie Prezesa Rady Ministrów z dnia 20 czerwca 2002 r. w sprawie „Zasad techniki prawodawczej", t.j. Dz. U. z 2016 r., poz. 283.

Ustawa z dnia 13 marca 2003 r. o szczególnych zasadach rozwiązywania z pracownikami stosunków pracy z przyczyn niedotyczących pracowników, t.j. Dz. U. z 2018 r., poz. 844 z późn. zm.

\section{Orzecznictwo:}

Wyrok Sądu Apelacyjnego w Katowicach z dnia 20 lutego 1990 r., III APr 5/91, OSP 1991 nr 11, poz. 307. Uchwała 7 sędziów Sądu Najwyższego Izba Administracyjna, Pracy i Ubezpieczeń Społecznych z dnia 23 kwietnia 1990 r., sygn. III PZP 3/90, OSP 1991, nr 2, poz. 53.

Wyrok Sądu Najwyższego z dnia 10 października 1990 r., I PR 297/90, Orzecznictwo Sądów Polskich 1991, nr 4, poz. 94.

Wyrok Sądu Najwyższego z dnia 19 grudnia 1990 r., I PR 391/90, OSNC 1992, Nr 11, poz. 206.

Uchwała 7 sędziów Sądu Najwyższego z dnia 9 lipca 1992 r., sygn. I PZP 20/92, OSNCP 1993, nr 1-2, poz. 2.

Postanowienie Sądu Najwyższego - Izba Pracy, Ubezpieczeń Społecznych i Spraw Publicznych z dnia 9 maja 2006 r., sygn. II PZP 2/06, OSNAPiUS 2007 nr 9-10, poz. 133.

Wyrok Sądu Apelacyjnego w Gdańsku z dnia 5 czerwca 2013 r., III AUa 1246/13, Legalis nr 999142.

\section{Biogram}

Joanna Radziszewska - absolwentka Wydziału Prawa i Administracji Uniwersytetu Gdańskiego, kierunek prawo. W latach 2007-2008 ukończyła studia podyplomowe z zakresu prawa zamówień publicznych oraz funduszy Unii Europejskiej. Po odbyciu aplikacji radcowskiej, w roku 2005 uzyskała tytuł radcy prawnego. Wpisana na listę mediatorów przy Okręgowej Izbie Radców Prawnych w Gdańsku. Od 2016 r. uczestnik studiów doktoranckich z zakresu prawa na Uniwersytecie Gdańskim. W kwietniu 2019 r. otworzyła przewód doktorski w Katedrze Teorii i Filozofii Państwa i Prawa, gdzie pracuje nad doktoratem pod opieką promotora dr. hab., prof. UG Kamila Zeidlera. Jej zainteresowania badawcze koncentrują się na prawie reklamy, prawie autorskim i prawie pracy. Prowadziła liczne szkolenia z zakresu szeroko pojętego prawa cywilnego, prawa pracy, prawa zamówień publicznych oraz prawa autorskiego i własności intelektualnej. Bardzo aktywna zawodowo - posiada dwudziestoletnie doświadczenie praktyczne w zakresie wykonywania kompleksowej obsługi prawnej na rzecz podmiotów gospodarczych o różnym statusie, w tym w szczególności spółek Skarbu Państwa. 